\title{
Efektivitas Pembelajaran Tematik (PS) Terhadap Kemampuan Berpikir Kritis Peserta Didik
}

\author{
Marsita Dewi Widyaningrum ${ }^{1 *}$, Naniek Sulistya Wardani $^{2}$
}

${ }^{13}$ Prodi Pendidikan Guru Sekolah Dasar, Universitas Halmahera, Indonesia

\begin{tabular}{l} 
A R T I C L E I N F O \\
\hline Article history: \\
Received 18 Desember \\
2019 \\
Received in revised form \\
30 Desember 2019 \\
Accepted 15 Januari 2020 \\
Available online 20 \\
Februari 2020 \\
\hline Kata Kunci: \\
tematik, problem \\
solving, berpikir kritis \\
Keywords: \\
thematic problem \\
solving, critical \\
thinking
\end{tabular}

\begin{abstract}
A B S T R A K
Penelitian ini bertujuan untuk mengetahui efektivitas pembelajaran tematik problem solving (PS) terhadap kemampuan berpikir kritis peserta didik kelas 4 SD. Penelitian dilaksanakan di SDN Tingkir Tengah 01 Salatiga dan SDN Tingkir Tengah 02 Salatiga. Subyek penelitian ini adalah siswa kelas 4 SDN Tingkir Tengah 01 sebagai kelas kontrol dan SDN Tingkir Tengah 02 sebagai kelas eksperimen. Jenis penelitian eksperimen semu dengan desain penelitian nonequivalent control group design. Teknik pengambilan sampel adalah teknik purposive stratified quota sampling. Teknik pengumpulan data terdiri teknik tes dan non tes. Instrumen teknik tes berupa butir soal dengan bentuk soal pilihan ganda dan instrumen teknik non tes berupa lembar observasi yang dilengkapi dengan rubrik penilaian kemampuan berpikir kritis. Teknik analisis data menggunakan teknik uji-t. Hasil penelitian menunjukkan thitung 2,372 > 2,000 dan signifikansi (2-tailed) 0,021 < 0,05, artinya $\mathrm{H}_{\mathrm{a}}$ diterima dan $\mathrm{H}_{\mathrm{o}}$ ditolak, JAdi, terdapat perbedaan efektivitas pembelajaran tematik problem solving (PS) dan pembelajaran konvensional terhadap kemampuan berpikir kritis peserta didik kelas 4 SD tema 7 Indahnya Keberagaman di Negeriku, subtema 1 Keberagaman Suku Bangsa dan Agama di Negeriku Pembelajaran 2.
\end{abstract}

\section{A B S T R A C T}

This study aims to determine the effectiveness of thematic learning problem solving (PS) on the critical thinking skills of 4th grade students. The study was conducted at SDN Tingkir Tengah 01 Salatiga and SDN Tingkir Tengah 02 Salatiga. The subjects of this study were students in grade 4 at SDN Tingkir Tengah 01 as a control class and SDN Tingkir Tengah 02 as an experimental class. This type of quasi-experimental research with a nonequivalent control group design research design. The sampling technique is a purposive stratified quota sampling technique. Data collection techniques consisted of test and non-test techniques. The test technical instrument is in the form of items with multiple choice questions and non-test technical instruments in the form of observation sheets which are equipped with rubric of critical thinking ability assessment. The data analysis technique used t-test technique. The results showed $t$ count 2,372> 2,000 and significance (2-tailed) $0.021<0.05$, meaning Ha was accepted and Ho was rejected, so there were differences in the effectiveness of thematic learning Theme 7 Subtheme 1 problem solving (PS) and conventional thematic learning towards critical thinking skills of 4 th grade students. The difference in the effectiveness of thematic learning towards the critical thinking skills of 4th grade students is 6.35 .

Copyright (C) Universitas Pendidikan Ganesha. All rights reserved.

\section{Pendahuluan}

Pendidikan seringkali dijadikan sebagai salah satu sarana seseorang untuk dapat mengembangkan ilmu pengetahuan, sikap sosial, dan keterampilan yang telah dimiliki dan sesuai dengan kebutuhan. Pendidikan di Indonesia saat ini menggunakan pembelajaran berbasis kurikulum 2013. Kurikulum 2013 dilaksanakan dengan menerapkan pembelajaran tematik terpadu (Permendikbud No.22 Tahun 2016).

Pembelajaran tematik terpadu difokuskan pada pembelajaran yang dapat memungkinkan peserta didik baik secara individual maupun kelompok lebih aktif untuk menggali dan menemukan konsep serta prinsip-prinsip keilmuan holistik, bermakna, dan autentik (Rusman, 2012: 254). Ciri-ciri pembelajaran tematik terpadu difokuskan pada pembelajaran yang berpusat pada peserta didik, dan pembelajaran yang memberikan pengalaman secara langsung kepada peserta didik (Mustamilah, 2015: 93-94). Tingkat

\footnotetext{
${ }^{1}$ Corresponding author.

E-mail addresses: marsitadewi19@gmail.com¹(marsita),wardani.naniek@gmail.com²(wadani)
} 
Pendidikan Sekolah Dasar (SD) juga sudah menerapkan pembelajaran tematik terpadu namun tidak semua mata pelajaran digabungkan menjadi satu pembelajaran yaitu pada mata pelajaran Matematika dan Pendidikan Jasmani Olahraga dan Kesehatan (PJOK) sebagai mata pelajaran yang berdiri sendiri untuk kelas IV, V, dan VI (Permendikbud Nomor 57 Tahun 2014).

Pembelajaran tematik terpadu bertujuan untuk memberikan pengalaman secara langsung kepada peserta didik (Wardani, 2013). Adapun pembelajaran tematik terpadu diarahkan kepada tiga ranah pembelajaran, yaitu pembelajaran kognitif, afektif, dan psikomotorik (Taksonomi Bloom). Pada ranah pembelajaran afektif (sikap) dapat dilihat atau diperoleh berdasarkan kegiatan-kegiatan peserta didik selama mengikuti pembelajaran berdasarkan, "sikap menerima, menjalankan, mematuhi, mengamalkan, menghayati, dan menghargai" yang melibatkan secara langsung peserta didik dalam rangka memberikan pengalaman langsung kepada peserta didik. Ranah kedua yaitu ranah kognitif (pengetahuan) dapat dilihat atau diperoleh pada kegiatan peserta selama mengikuti kegiatan pembelajaran berdasarkan, "kegiatan mengamati, menanya, mencoba, menalar, mengkaji, dan mencoba" sesuai dengan KKO yang digunakan dalam pembelajaran (Permendikbud No. 103 Tahun 2014). Ranah yang ketiga yaitu ranah psikomotorik (keterampilan), ranah psikomotor lebih difokuskan kepada kegiatan atau aktivitas peserta didik sehingga diharapkan mampu meningkatkan keaktifan, kemandirian, dan kemampuan berpikir kritis peserta didik.

Berdasarkan pengamatan kepada peserta didik di kelas 4, Pada saat ini SD ini sudah melaksanakan kurikulum 2013, akan tetapi dalam pembelajaran belum sepenuhnya menerapkan sintaks pembelajaran kurikulum 2013, dan pembelajaran masih didominasi pada aktivitas guru. Misalnya guru belum sepenuhnya menggunakan model-model pembelajaran yang inovatif, guru hanya menggunakan model pembelajaran numberhead together dan discovery learning sebagai penunjang pembelajaran, peserta didik diberikan suatu permasalah, kemudian berdiskusi, dan mempresentasikan hasil diskusi, sehingga menjadikan peserta didik kurang begitu aktif dalam pembelajaran dan pada saat guru mengajukan pertanyaan peserta didik cenderung hanya diam. Melalui hasil pengamatan juga terlihat peserta didik terkesan kurang mampu mengembangkan kemampuan berpikirnya dan tingkat kemampuan berpikir peserta didik hanya sampai pada tingkat memahami saja. Salah satu pembelajaran yang mampu melibatkan peserta didik dalam aktivitas pembelajaran dan mampu meningkatkan kemampuan berpikir kritis peserta didik adalah pembelajaran problem solving (PS).

Pembelajaran PS merupakan pembelajaran inovatif berbasis pemecahan masalah yang mampu melatih kemampuan berpikir peserta didik secara optimal melalui sebuah proses kerja kelompok atau tim, serta mampu melatih peserta didik untuk membudayakan, mengasah, menguji, dan mengembangkan kemampuan cara berpikir secara kesinambungan dalam menganalisis, menemukan informasi, dan menarik kesimpulan terhadap masalah yang dihadapi (Rusman 2011: 229). Pendapat lain juga diungkapkan oleh Eriyanti, Evi \& Suryanti (2018) menjelaskan pendekatan PS merupakan pembelajaran berbasis pemecahan masalah yang berpusat pada peserta didik dengan melibatkan secara langsung peserta didik dalam pemecahan masalah yang dihadapi dengan melakukan pengkajian masalah merumuskan masalah, mengumpulkan informasi, menganalisis, dan menarik kesimpulan. Pembelajaran pendekatan PS juga dapat melatih kemampuan bekerja sama, berdikusi, dan berkomunikasi dalam kelompok. Pendapat yang hampir sama juga dikemukakan oleh Masjid, Abdul (Andayani, Sri: 2018) menjelaskan pendekatan PS merupakan pembelajaran yang berbasis pemecahan masalah yang berorientasi pada "learner centered" yang menggunakan metode mencari data, menganalisis data, sampai dengan menarik kesimpulan yang dilakukan melalui kerja kelompok. Jadi dapat disimpulkan bahwa pembelajaran PS yaitu pembelajaran berbasis pemecahan masalah "learned centered" dengan melakukan pengkajian terhadap masalah dengan cara mengumpulkan informasi, mengananalisis, dan menarik kesimpulan yang dilakukan secara kelompok sehingga mampu melatih bekerja sama, bediskusi, berkomunikasi, dan kemampuan berpikir. Model pembelajaran problem solving (PS) merupakan salah satu pendekatan pembelajaran yang inovatif dengan menerapkan pembelajaran berbasis masalah yang harus dipecahkan oleh peserta didik secara berkelompok kecil untuk mencari dan menemukan solusi, jawaban atau informasi terkait dengan permasalahan yang sedang dihadapinya. Pembelajaran PS mendorong peserta didik untuk mampu dapat meningkatkan kemampuan berpikir, berbicara, bekerjasama dalam menyelesaikan setiap permasalahan. Dengan menggunakan model pembelajaran PS, peserta didik dilatih untuk dapat memiliki kemampuan berpikir tingkat tinggi yang baik, berbicara yang bak, dan bekerja sama dalam kelompok.

Langkah-langkah pembelajaran PS yang dikemukakan oleh Wena (2011: 56) yang menjelaskan sebagai berikut: 1) Identifikasi masalah (masalah tumbuh dari dalam diri peserta didik), 2) Membuat jawaban sementara atas permasalahan, 3) Merencanakan pemecahan masalah, 4) Mencari informasi berdasarkan data atau keterangan yang didapatkan untuk menguji atas jawaban sementara dengan mencari buku, bertanya, menyelidiki/meneliti, berdiskusi, dan sebagainya, dan 5) Menarik kesimpulan. 
Langkah-langkah pembelajaran PS hampir sama juga dikemukakan oleh Jacobsen (Rochmawati, 2012: 6) sebagai berikut: 1) Mengidentifikasi masalah, 2) Menegaskan masalah (peserta didik diminta untuk mengindentifikasi sebab akibat timbulnya masalah), 3) Memilih sebuah strategi untuk memilih dan menentukan strategi yang tepat dalam menyelesaikan masalah, 4) Melaksanakan strategi, dan 5) Mengevaluasi hasil dengan menarik kesimpulan tentang permasalahan yang telah diselesaikan.

Langkah-langkah PS juga dikemukakan oleh Hamiyah dan Jauhar (2014: 129) sebagai berikut, 1) Menyiapkan permasalahan yang akan dipecahkan, 2) Menyajikan masalah, 3) Mengumpukan data atau informasi yang dapat digunakan untuk memecahkan masalah, 4) Merumuskan hipotesis, 5) Menguji hipotesis, dan 6) Penarikan kesimpulan.

Langkah-langkah PS dapat disimpulkan sebagai berikut: 1) menyimak penjelasan, 2) mengidentifikasi masalah, 3) menganalisis masalah, 4) mengumpulkan informasi, 5) membuat laporan hasil pengamatan, 6) menyampaikan hasil pengamatan, 7) memberikan tanggapan, dan 8) mengerjakan tes tertulis.

Desain pembelajaran PS digunakan pada pembelajaran tema 7 Indahnya Keberagaman di Negeriku subtema 1 Keberagaman Suku Bangsa dan Agama di Negeriku Pembelajaran 2 yang terdiri dari 3 mata pelajaran yaitu Bahasa Indonesia dengan KD 3.7 dan 4.7, IPA dengan KD 3.3 dan 4.3, dan SBdP dengan KD 3.2 dan 4.2 melalui langkah-langkah sebagai berikut: 1) Menyimak penjelasan guru tentang keberagaman suku bangsa, agama, budaya, dana bahasa di Indonesia, 2) Mengidentifikasi macam-macam bentuk keberagaman suku bangsa, agama, budaya, dana bahasa di Indonesia, 3) Menganalisis masalah keberagaman suku bangsa, agama, budaya, dana bahasa di Indonesia, 4) Mengumpulkan informasi dengan mengklasifikasikan permasalahan (suku bangsa, agama, budaya, dan bahasa) yang ada di Indonesia, 4) Membuat laporan hasil pengamatan, 5) Menyampaikan hasil pengamatan, 6) Memberikan tanggapan, dan 7) Mengerjakan tes tertulis. Langkah-langkah pembelajaran PS akan diuji cobakan untuk mengetahui efektivitas pembelajaran PS dalam meningkatkan kemampuan berpikir kritis peserta didik.

Beberapa ahli penelitian yang relevan yaitu penelitian yang dilakukan oleh Evi Eriyanti \& Suryati (2018) dengan judul Pengaruh Model Creative Problem Solving (CPS) Terhadap Kemampuan Berpikir Kritis Pembelajaran IPA Kelas IV SDN Kemuning Sidoarjo. Tujuan penelitian dilakukan untuk mengetahui pengaruh model creative problem solving (CPS) terhadap kemampuan berpikir kritis pembelajaran ipa kelas IV SDN Kemuning Sidoarjo. Hasil penelitian menunjukkan bahwa pembelajaran Creative Problem Solving berpengaruh terhadap kemampuan berpikir kritis peserta didik. Terdapat perbedaan rata-rata pada skor posttest kelompok eksperimen dan kelompok kontrol. Skor rata-rata posttest kelompok ekperimen 86,93, dan skor rata-rata posttest kelompok kontrol 76,83, terdapat perbedaan skor rata-rata sebesar 10,1. penelitian yang dilakukan oleh made rohani, dkk (2018) dengan judul penelitian "Pengaruh Penggunaan Metode Creative Problem Solving Terhadap Hasil Belajar IPA Dengan Kovariabel Kemampuan Berpikir Kritis Pada Siswa Kelas V SD". Tujuan penelitian untuk mengetahui pengaruh penggunaan metode creative problem solving terhadap hasil belajar IPA dengan kovariabel kemampuan berpikir kritis pada siswa kelas V SD. Hasil penelitian menunjukkan terdapat pengaruh yang signifikan terdapat pengaruh terhadap hasil belajar IPA setelah menggunakan pembelajaran creative problem solving yang dikendalikan dengan kemampuan berpikir kritis dengan hasil $\mathrm{F}_{\text {reg }}=43,232 ; \mathrm{p}<0,05$.

Kemampuan berpikir kritis merupakan kemampuan berpikir secara logis untuk menjawab sebuah pertanyaan-pertanyaan atau memberikan solusi terhadap permasalahan yang terjadi dengan memberikan alasan atau bukti yang jelas. Menurut Alghafri \& Nizam (2014: 519), Kuswana, (2012: 19), dan Eriyanti, Evi \& Suryati (2018) kemampuan berpikir kritis kemampuan berpikir dalam memberikan jawaban atas permasalahan disertai dengan alasan dan bukti yang jelas. Kemampuan berpikir kritis peserta didik akan nampak pada kemampuan identifikasi masalah, merumuskan masalah, menganalisis data, mensistesis data, pemecahan masalah, penarikan kesimpulan, dan evaluasi.

Penelitian ini bertujuan untuk mengetahui efektivitas pembelajaran tematik PS terhadap kemampuan berpikir kritis peserta didik kelas 4 SD.

Penerapan desain pembelajaran PS dilakukan untuk mengetahui efektivitas pembelajaran tematik PS terhadap kemampuan berpikir kritis peserta didik kelas 4 SD pada Tema 7 Subtema 1 Pembelajaran 2 akan mengacu pada design penelitian yang dilakukan sebagai berikut: 


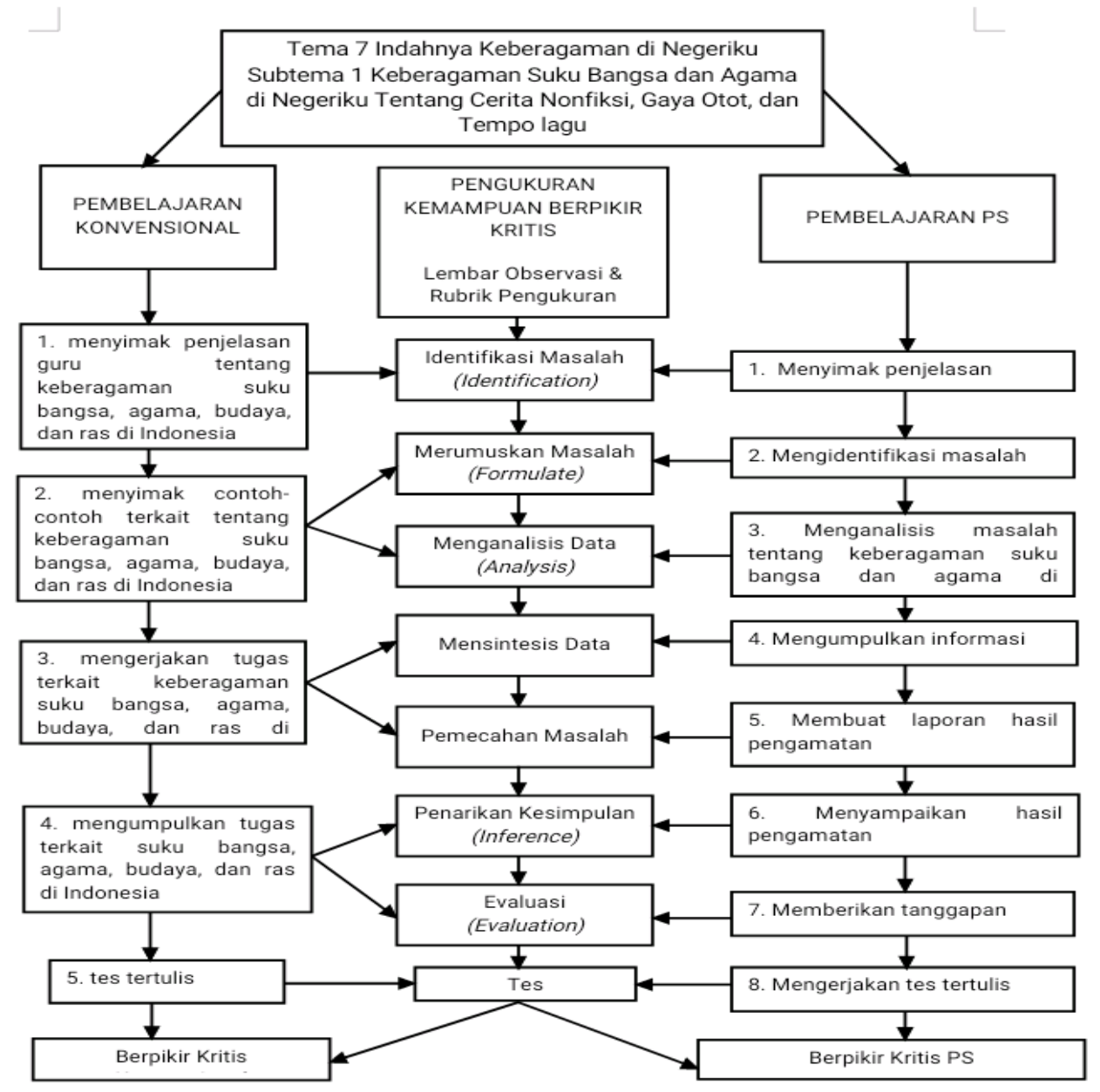

Gambar 01. Design penelitian yang dilakukan

\section{Metode}

Jenis penelitian ini adalah jenis penelitian eksperimen. Sugiyono (2013:17) menjelaskan bahwa penelitian eksperimen merupakan suatu penelitian yang dilakukan untuk mencari pengaruh perlakuan tertentu dalam kondisi yang dikendalikan, variabel-variabel yang dapat mempengaruhi proses eksperimen atau perlakuan dapat dikontrol secara ketat. Penelitian eksperimen dilakukan secara langsung di kelompok kontrol dan kelompok eksperimen. Penelitian ini termasuk eksperimen semu (quasi eksperimen) dengan rancangan pemberian pretest dan posttest pada kelompok kontrol dan kelompok eksperimen.

Desain penelitian ini menggunakan Desain Quasi Eksperiment dengan pola Nonequivalent Control Group Design. Pola penelitian Nonequivalent Control Group Design dilakukan dengan memberikan pretest sebelum melakukan perlakuan dan posttest sesudah melakukan perlakuan baik pada kelompok kontrol dan kelompok eksperimen. Kegiatan pretest dan posttest bertujuan untuk mengetahui adanya perbedaan antara kelompok eksperimen dan kelompok kontrol supaya data yang diperoleh lebih signifikan. 
Penelitian eksperimen ini akan menyelidiki tentang hubungan sebab-akibat antara kelompok eksperimen dan kelompok kontrol. Desain penelitian eksperimen akan disajikan secara rinci dalam tabel 1 sebagai berikut:

Tabel 01. Populasi Penelitian

\begin{tabular}{lll}
\hline $\mathbf{0}_{1}$ & $\mathrm{X}$ & $\mathbf{O}_{2}$ \\
\hline $\mathbf{0}_{3}$ & & $\mathbf{0}_{4}$
\end{tabular}

Sumber : Sugiyono (2017: 79)

Keterangan:

$\mathrm{X}$ : Perlakuan menggunakan pembelajaran PS

$\mathrm{O}_{1}$ : Hasil pretest kelompok eksperimen

$\mathrm{O}_{2}$ : Hasil posttest kelompok eksperimen

$\mathrm{O}_{3}$ : Hasil pretest kelompok kontrol

$\mathrm{O}_{4}$ : Hasil posttest kelompok kontrol

Populasi dalam penelitian ini adalah seluruh objek atau subyek yang memiliki kualitas dan karakteristik tertentu dalam suatu wilayah yang telah ditentukan oleh seorang peneliti untuk dapat dipelajari dan ditarik kesimpulan (Sugiyono, 2017:131). Populasi yang digunakan dalam penelitian ini adalah seluruh peserta didik kelas 4 di SD Negeri Tingkir Tengah 01 dan SD Negeri Tingkir Tengah 02 Kota Salatiga.

Sampel merupakan sebagian kecil dari populasi yang akan diteliti (Arikunto, 2013: 174). Sampel dinyatakan sebagai bagian dari seluruh jumlah dan karakteriktik yang dimiliki oleh populasi (Sugiyono, 2017: 132). Teknik pengambilan sampel dalam penelitian ini menggunakan teknik purposive stratified quota sampling, yaitu teknik pengambilan sampel dengan mendasarkan pada tujuan penelitian, kemudian menentukan jenjang kelas dan jumlah responden yang digunakan. Tujuan penelitian adalah untuk mengetahui efektivitas pembelajaran tematik problem solving (PS) terhadap kemampuan berpikir kritis peserta didik kelas 4 SD. Dengan demikian, sekolah yang dipilih untuk penelitian adalah sekolah yang menerapkan pembelajaran tematik, peserta didik kelas 4, dan tiap rombongan belajarnya terdiri lebih dari 25 peserta didik

Variabel penelitian terdiri dari dua variabel yaitu variabel bebas dan variabel terikat. Variabel bebas dalam penelitian ini adalah pembelajaran tematik problem solving (PS). Pembelajaran tematik problem solving (PS) merupakan pembelajaran tematik yang berbasis masalah dan melakukan pengkajian terhadap masalah dengan cara mengumpulkan informasi, menganalisis, dan menarik kesimpulan secara berkelompok. Sedangkan variabel terikat adalah kemampuan berpikir kritis. Kemampuan berpikir kritis adalah suatu kemampuan dalam proses kegiatan pemecahan masalah, mengambil keputusan, membujuk, menganalisis asumsi, dan melakukan penelitian ilmiah. Kemampuan berpikir kritis dapat dilihat dalam tahapan mengidentifikasi masalah, merumuskan masalah, menganalisis data, mensintesis data, pemecahan masalah, penarikan kesimpulan, dan evaluasi.

Teknik pengumpulan data menggunakan teknik tes dan non tes. Instrumen teknik tes adalah butir soal yang berbentuk pilihan ganda dan instrumen teknik non tes adalah lembar observasi yang dilengkapi dengan rubrik penilaian kemampuan berpikir kritis.

Teknik analisis data menggunakan teknik uji t-test. Syarat dalam melakukan uji t-test adalah kelompok eksperimen dan kelompok kontrol berdistribusi normal dan homogen. Sebelum instrumen digunakan untuk mengetahui bahwa dua kelompok terdistribusi normal dan homogen, instrumen penelitian melakukan uji valid dan reliabel terlebih dahulu. Pengujian validitas dan reliabilitas instrumen menggunakan bantuan SPSS 24.0. Anwar (2011: 158) menjelaskan jika hasil pengujian menunjukkan koefisien korelasi cronbhasch's alpha butir soal $\geq 0,30$, maka butir soal dinyatakan valid, dan apabila koefisien korelasi butir soal $<0,30$, maka butir soal dinyatakan tidak valid. Hasil uji validitas terhadap 20 butir soal menunjukkan $r \geq 0,30$ yaitu antara 0,375 - 0,525, maka butir soal valid.

Hasil uji reliabilitas instrumen butir soal menunjukkan cronbhasch's alpha sebesar 0,851 >0,05, maka instrumen butir soal dinyatakan sangat reliabel. Setelah instrumen butir soal melakukan uji coba validitas dan reliabilitas, maka langkah selanjutnya yaitu instrument penelitian melakukan pengujian normalitas dan homogenitas. Uji normalitas digunakan untuk mengetahui apakah hasil pretest yang digunakan di kelompok eksperimen dan kelompok kontrol menunjukkan terdistribusi normal atau tidak. Pengujian normalitas menggunakan uji Kolmogorov-Smirnov karena jumlah responden kurang dari 50. 
Jika hasil pengujian Kolmogorov-Smirnov menunjukkan nilai signifikasi $<0,05$, maka kelompok kontrol maupun kelompok eksperimen tidak terdistribusi normal, dan jika hasil pengujian Kolmogorov-Smirnov menunjukkan signifikasi $>0,05$, maka kelompok kontrol maupun kelompok eksperimen terdistribusi normal. Hasil uji distribusi normalitas pada kelompok eksperimen dan kelompok kontrol disajikan pada tabel 02 sebagai berikut:

Tabel 02. Hasil Uji Normalitas Kelompok Eksperimen dan Kelompok Kontrol

\begin{tabular}{cccc}
\hline \multirow{2}{*}{ Kelompok } & \multicolumn{3}{c}{ Kolmogorov-Smirnov $^{\mathrm{a}}$} \\
\cline { 2 - 4 } & Statistic & $\mathrm{df}$ & Sig. \\
\hline Eksperimen & 0,120 & 30 & 0,200 \\
\hline Kontrol & 0,146 & 33 & 0,072 \\
\hline
\end{tabular}

Berdasarkan hasil uji normalitas pada kelompok eksperimen dan kelompok kontrol, menunjukkan bahwa nillai signifikansi kelompok eksperimen sebesar 0,200>0,05 artinya data terdistribusi normal, sedangkan pada kelompok kontrol menunjukkan nilai signifikansi sebesar $0,72>0,05$, artinya data terdistribusi normal. Jadi dapat disimpulkan bahwa kedua kelompok penelian terdistribusi normal.

Data yang sudah terdistribusi normal, maka langkah selanjutnya yaitu uji homogenitas. Uji homogenitasi dilakukan untuk mengetahui varian data yang dihasilkan oleh kelompok eksperimen (problem solving) dan kelompok kontrol (konvensional) dengan menggunakan hasil posttest. Dasar yang digunakan untuk uji homogenitas yaitu: Jika nilai signifikan $<0.05$ maka data dinyatakan tidak sama atau tidak homegen, dan apabilan nilai signifikan $>0.05$ maka data dinyatakan sama atau homogen. Data yang digunakan harus bersifat homogen untuk dapat mengetahui bahwa terdapat kesamaan antara dua varian. Hasil uji homogenitas pada kelompok eksperimen dan kelompok kontrol disajikan dalam tabel dinawah ini:

Tabel 03. Hasil Uji Homogenitas Kelompok Eksperimen dan Kelompok Kontrol

\begin{tabular}{cccc}
\hline Levene Statistic & df1 & df2 & Sig. \\
\hline 0,086 & 1 & 61 & 0,770 \\
\hline
\end{tabular}

Berdasarkan hasil pengujian homogenitas kelompok eksperimen dan kelompok kontrol menunjukkan signifikansi $0,770>0,05$, maka kelompok eksperimen dan kelompok kontrol mempunyai varian yang sama atau homogen. Langkah selanjutnya akan menguji hipotesis dengan menggunakan teknik analisis uji t-test yang independent samples test.

\section{Hasil dan Pembahasan}

Penelitian dilakukan untuk menguji hipotesis bahwa Terdapat perbedaan efektivitas pembelajaran tematik tema 7 subtema 1 dengan menggunakan pendekatan problem solving terhadap kemampuan berfikir kritis peserta didik kelas 4 SD Semester 2.

Teknik analisis data menggunakan teknik uji independent samples test. Teknik uji independent samples test yaitu pengujian data posttest pada kelompok eksperimen dan kelompok kontrol dengan kriteria: 1) Jika nilai signifikansi (2-tailed) $<0,05$, maka $\mathrm{H}_{o}$ ditolak dan $\mathrm{H}_{a}$ diterima, dan 2) Jika nilai signifikansi (2-tailed) $>0,05$, maka $\mathrm{H}_{\mathrm{o}}$ diterima dan $\mathrm{H}_{\mathrm{a}}$ ditolak.

Pelaksanaan pembelajaran pada kelompok eksperimen akan diberikan perlakuan dengen menggunakan pembelajaran problem solving sedangkan untuk kelompok kontrol tanpa perlakuan dengan menggunakan pembelajaran konvensional. Pada kelompok eksperimen pembelajaran menggunakan problem solving (PS) akan dilakukan melalui langkah-langkah sebagai berikut, yaitu mengidentifikasi masalah, merumuskan masalah, menganalisis masalah, mensintesis data, pemecahan masalah, penarikan kesimpulan, dan evaluasi. Sedangkan, pada pembelajaran kelompok kontrol pembelajaran menggunakan pembelajaran konvensional akan dilakukan melalui langkah-langkah sebagai berikut, yaitu menyimak penjelasan guru, menyimak contoh-contoh, mengerjakan tugas, mengumpulkan tugas, dan evaluasi. Langkah-langkah pembelajaran di kelompok kontrol ini merupakan langkah-langkah pembelajaran rutin yang masih dilakukan di sekolah setiap harinya. Penelitian akan dilakukan pada pembelajaran tematik tema 7 Indahnya Keberagaman di Negeriku subtema 1 Keberagaman Suku Bangsa dan Agama di Negeriku 
pembelajaran ke 2. Pada akhir kegiatan pembelajaran kedua kelompok penelitian (kelompok eksperimen dan kelompok kontrol) akan diberikan posttest untuk mengukur kemampuan berpikir kritis. Hasil ratarata skor posttest untuk masing-masing kelompok, secara rinci disajikan dalam tabel 04 berikut ini.

Tabel 04. Skor Rata-rata Hasil Posttest Kelompok Eksperimen dan Kelompok Kontrol

\begin{tabular}{llllll}
\hline Posttest & Kelas & N & Mean & Std. Deviation & Std. Error Mean \\
\hline $\begin{array}{l}\text { Kemampuan } \\
\text { berpikir kritis }\end{array}$ & $\begin{array}{l}\text { Kelompok } \\
\text { Eksperimen }\end{array}$ & 30 & 78,17 & 10,945 & 1,998 \\
\cline { 2 - 6 } & $\begin{array}{l}\text { Kelompok } \\
\text { Kontrol }\end{array}$ & 33 & 71,82 & 10,294 & 1,792 \\
\hline
\end{tabular}

Sumber: Data Primer

Tabel 04 menunjukkan skor rata-rata hasil posttest kelompok eksperimen sebesar 78,17, dan kelompok kontrol sebesar 71,82. Perbedaan rata-rata skor post-test kemampuan berpikir kritis antara kelompok eksperimen dan kelompok kontrol sebesar 6,35. Meskipun distribusi kemampuan berfikir kritis antara kelompok eksperimen dan kelompok kontrol mengikuti kurve normal dan homogen. Perbedaan hasil kemampuan berpikir kritis terjadi, karena ada perbedaan perlakuan, sehingga proses pembelajaran yang berlangsung berbeda.

Perbedaan hasil posttest antara kelompok eksperimen dan kelompok kontrol, dikuatkan dengan uji t-test. Hasil uji $t$-test disajikan melalui tabel 05 sebagai berikut

Tabel 05. Hasil Uji Independent Samples Test

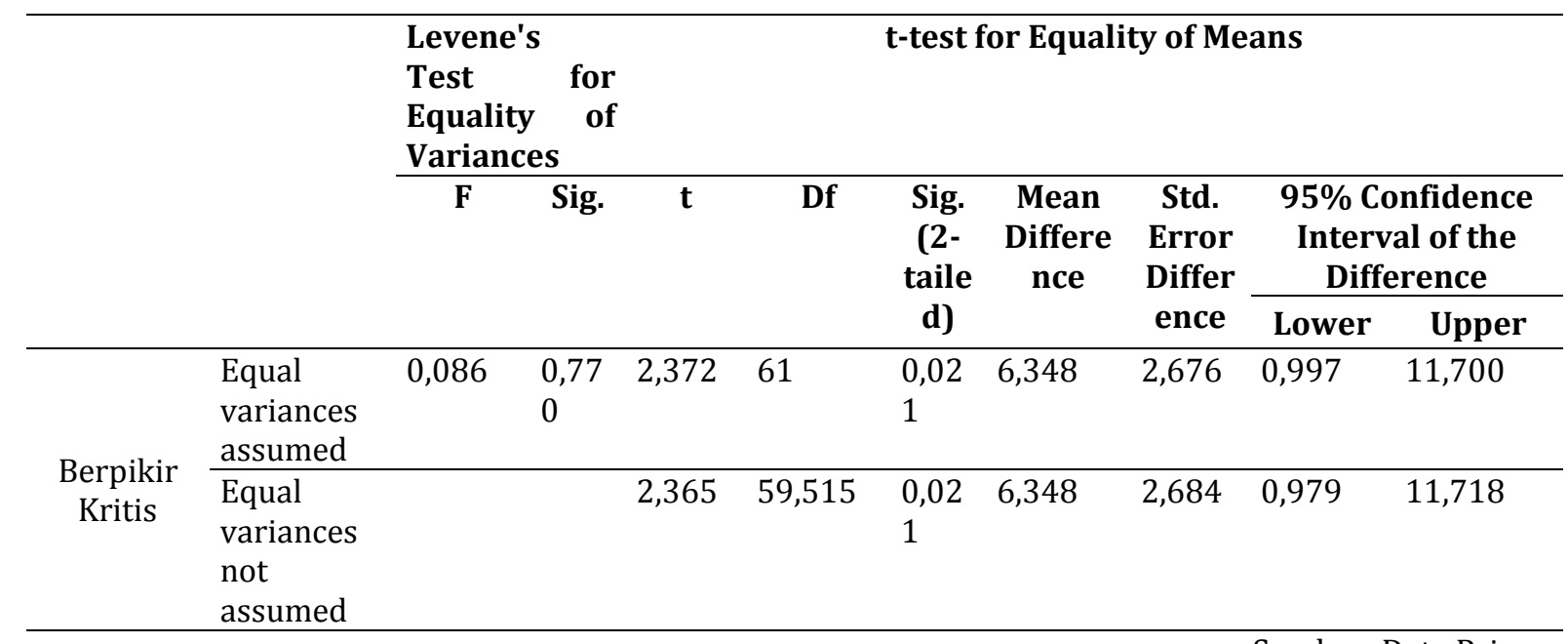

Berdasarkan tabel 4 hasil uji t test, diperoleh t hitung 2,372 >2,000 t tabel dan signifikansi 0,021< 0,05, artinya $\mathrm{H}_{\mathrm{a}}$ diterima dan $\mathrm{H}_{0}$ ditolak, maka terdapat perbedaan efektivitas pembelajaran tema 7 Indahnya Keberagaman di Negeriku subtema 1 Keberagaman Suku Bangsa dan Agama di Negeriku pembelajaran 2 problem solving (PS) terhadap kemampuan berpikir kritis peserta didik kelas 4 SD. Perbedaan efektivitas pembelajaran tema 7 Indahnya Keberagaman di Negeriku subtema 1 Keberagaman Suku Bangsa dan Agama di Negeriku pembelajaran 2 dengan pendekatan problem solving (PS) terhadap kemampuan berpikir kritis peserta didik kelas 4 SD adalah sigifikan, artinya terdapat perbedaan yang bermakna.

Kemampuan berpikir kritis peserta didik kelompok eksperimen dan kelompok kontrol dalam pembelajaran tematik dapat diklasifikasikan menjadi 3 kategori yaitu sangat kritis, kritis, dan kurang kritis. Dari hasil penelitian, kemampuan berpikir kritis kelompok eksperimen dan kelompok kontrol diklasifikasikan seperti dalam tabel 06 berikut ini. 
Tabel 06. Klasifikasi Kemampuan Berpikir Kritis Kelompok Eksperimen Dan Kelompok Kontrol

\begin{tabular}{llcccc}
\hline \multirow{2}{*}{ Interval Kelas } & Kategori & \multicolumn{2}{c}{ Kelas Eksperimen } & \multicolumn{2}{c}{ Kelas Kontrol } \\
\cline { 3 - 6 } & Frekuensi & $\begin{array}{c}\text { Persentase } \\
\mathbf{( \% )}\end{array}$ & Frekuensi & $\begin{array}{c}\text { Persentase } \\
(\%)\end{array}$ \\
\hline $28-22,75$ & Sangat kritis & 22 & 73 & 17 & 52 \\
\hline $22,74-17,50$ & Kritis & 8 & 27 & 14 & 42 \\
\hline $17,49-12,25$ & Kurang Kritis & 0 & 0 & 2 & 6 \\
\hline Jumlah & & $\mathbf{3 0}$ & $\mathbf{1 0 0}$ & $\mathbf{3 3}$ & $\mathbf{1 0 0}$ \\
\hline
\end{tabular}

Berdasarkan tabel 6 menunjukkan bahwa dalam pembelajaran tematik kelompok eksperimen terdapat $73 \%$ dari seluruh peserta berkemampuan sangat kritis, sedangkan di kelompok kontrol yang berkemampuan sangat kritis hanya mencapai 52\% dari seluruh peserta. Terdapat perbedaan jumlah peserta didik yang berkemampuan sangat kritis sebesar 21\% dari seluruh peserta atau 5 peserta. Jadi jumlah peserta didik yang berkemampuan sangat kritis, kelompok eksperimen lebih banyak daripada kelompok kontrol.

Hasil penelitian ini tentang kemampuan berfikir kritis, juga pernah dilakukan oleh Evi Eriyanti \& Suryati (2018) dengan judul Pengaruh Model Creative Problem Solving (CPS) Terhadap Kemampuan Berpikir Kritis Pembelajaran IPA Kelas IV SDN Kemuning Sidoarjo. Hasil penelitian menunjukkan bahwa pembelajaran Creative Problem Solving berpengaruh terhadap kemampuan berpikir kritis peserta didik. Terdapat perbedaan rata-rata pada skor posttest kelompok eksperimen dan kelompok kontrol. Skor ratarata posttest kelompok ekperimen 86,93 , dan skor rata-rata posttest kelompok kontrol 76,83 , terdapat perbedaan skor rata-rata sebesar 10,1. Perbedaan ini, kemudian diuji dengan uji $t$ test menghasilkan signifikasi $0,00<0,05$ maka $\mathrm{H}_{0}$ ditolak, artinya terdapat perbedaan pengaruh pembelajaran Creative Problem Solving terhadap kemampuan berpikir kritis peserta didik yang signifikan.

Hasil penelitian I Nym Budiana, dkk pada tahun 2013, juga menunjukkan terdapat perbedaan yang signifikan antara kelompok eksperimen dengan menerapkan pembelajaran creative problem solving dan kelompok kontrol yang menerapkan pembelajaran konvensional. Hasil penelitian menunjukkan rata-rata kemampuan berpikir kritis kelompok ekperimen sebesar 33,45 lebih tinggi dibandingkan kelompok kontrol dengan rata-rata kemampuan berpikir kritis sebesar 27,5. Penelitian ini juga menunjukkan hasil uji-t sebesar 3,42 > 2,021, maka $\mathrm{H}_{\mathrm{o}}$ ditolak, artinya terdapat perbedaan hasil pembelajaran creative problem solving antara kelompok eksperimen dan kelompok kontrol.

Penelitian sejalan juga dilakukan oleh Sisnanto pada tahun 2019, menunjukkan terdapat perbedaan antara pembelajaran problem solving dan group investigation terhadap kemampuan berpikir kritis peserta didik. Hasil penelitian menunjukkan $t$ hitung $>t$ tabel yaitu 3,970 > 3,1824 dan signifikan $0,000<0,05$, maka $\mathrm{H}_{\mathrm{o}}$ ditolak, artinya terdapat perbedaan antara pembelajaran problem solving dan group investigation terhadap kemampuan berpikir kritis.

Dari analisis tentang kemampuan berpikir kritis dengan perlakuan berupa pembelajaran PS menghasilkan perbedaan skor rata-rata kemampuan berpikir kritis kelompok eksperimen dan kelompok kontrol. Kemampuan berpikir kritis kelompok eksperimen lebih tinggi daripada kemampuan berpikir kritis kelompok kontrol. Maka terdapat perbedaan efektivitas pembelajaran tematik PS terhadap kemampuan berpikir kritis peserta didik kelas 4 SD.

Pelaksanaan pembelajaran tematik problem solving (PS) mampu menjadikan peserta didik berperan aktif dalam kegiatan pembelajaran, tidak ramai sendiri, mendengarkan instruksi guru, terlihat pada saat mengerjakan tugas, aktif dalam mengajukan pertanyaan, dan hadir dari awal pembelajaran sampai akhir pembelajaran. Hal ini dikarenakan, peserta didik diminta untuk selalu memberikan pendapat dalam kegiatan berdiskusi dalam kelas.

\section{Simpulan dan Saran}


Berdasarkan hasil penelitian dan pembahasan, maka kesimpulan yang dapat dirumuskan adalah terdapat efektivitas pembelajaran tema 7 Indahnya Keberagaman di Negeriku subtema 1 Keberagaman Suku Bangsa dan Agama di Negeriku pembelajaran ke 2 problem solving (PS) terhadap kemampuan berpikir kritis peserta didik kelas 4 SD. Hasil uji t-test 2,372 $>2,000$ dan nilai signifikansi $0,021<0,05$, artinya $\mathrm{H}_{a}$ diterima dan $\mathrm{H}_{0}$ ditolak. Maka terdapat efektivitas pembelajaran tematik problem solving (PS) terhadap kemampuan berpikir kritis pembelajaran tematik peserta didik kelas 4 SD.

Berdasarkan simpulan diatas, maka saran yang dapat diberikan adalah: 1) Guru hendaknya dapat menggunakan inovasi dalam pembelajaran dengan menggunakan pembelajaran problem solving (PS), 2) Guru hendaknya melatih dan meningkatkan kemampuan berpikir kritis peserta didik, 3) Guru dapat menggunakan pembelajaran problem solving (PS) untuk mencapai tujuan pembelajaran yang lebih bermakna.

\section{Daftar Rujukan}

Arikunto, S. (2013). Prosedur Penelitian Suatu Pendekatan Praktik. Jakarta: Rineka Cipta.

Emilia, Wasitohadi, \& Rahayu, T. S. (2019). Upaya Meningkatkan Hasil Belajar Siswa Dalam Pembelajaran Matematika Kelas V Dengan Menggunakan Metode Problem Solving. Jurnal Basicedu, 3(1), 101-105. https://jbasic.org/index.php/basicedu/article/view/84/81

Hamdani. (2011). Strategi Belajar Mengajar. Bandung: Pustaka Setia.

Mustamilah. (2015). Peningkatan Keterampilan Proses dan Hasil Belajar Mengunakan Model Problem Based Learning pada Subtema Merawat Tubuhku Siswa Kelas 1 SD Negeri 1 Gonoso-Wonosego. Jurnal Scholaria, 5(1), 92-102.

Menteri Pendidikan Dan Kebudayaan Republik Indonesia Nomor 103 Tahun 2014 Tentang Pembelajaran Pada Pendidikan Dasar Dan Pendidikan Menengah. Jakarta.

Nym, I Budiana. (2013). Pengaruh Model Creative Problem Solving (CPS) Terhadap Kemampuan Berpikir Kritis Siswapada Mata Pelajaran IPA Siswa Kelas V SD. Jurnal Undiksha, 1(1). https://ejournal.undiksha.ac.id/index.php/JPGSD/article/view/816

Oktaviani, W., Kristin, F., \& Anugraheni, I. (2018). Penerapan Model Pembelajaran Discovery Learning Untuk Meningkatkan Kemampuan Berpikir Kritis Dan Hasil Belajar Matematika Siswa Kelas 5 SD. Jurnal Basicedu, 2(2), 5-10. https://doi.org/10.31004/basicedu.v2i2.41

Permendikbud. Kurikulum 2013. Peraturan Menteri Pendidikan Dan Kebudayaan Republik Indonesia Nomor 65 Tahun 2013 Tentang Standar Proses Pendidikan Dasar Dan Menengah. Jakarta.

Permendikbud. Kurikulum 2013. Peraturan Menteri Pendidikan Dan Kebudayaan Republik Indonesia Nomor 22 Tahun 2016 Tentang Standar Proses Pendidikan Dasar dan Menengah. Jakarta.

Permendikbud. Kurikulum 2013. Peraturan Menteri Pendidikan Dan Kebudayaan Republik Indonesia Nomor 57 Tahun 2014 Tentang Kurikulum 2013 Sekolah Dasar/Madrasah Ibtidaiyah. Jakarta.

Rahayu, Tri Retno Ningsih. (2017). Pembelajaran Tematik Integratif Berbasis Scientific Approach Sekolah Dasar. Fakultas Ilmu Pendidikan Universitas Negeri Yogyakarta: Pendidikan Guru Sekolah Dasar.

Rohani, Made dkk. 2018. Pengaruh Penggunaan Metode Creative Problem Solving Terhadap Hasil Belajar Ipa Dengan Kovariabel Kemampuan Berpikir Kritis Pada Siswa Kelas V Sd. JIPP. 15(2).

Rohani, M., Lasmawan, I. W., \& Suastra, I. W. (2018). Pengaruh Penggunaan Metode Creative Problem Solving Terhadap Hasil Belajar IPA Dengan Kovariabel. 15, 143-153.

Rusman. (2012). Model-Model Pembelajaran. Depok: PT Rajagrafindo Persada. 245.

Sisnanto, Wahyudi, \& Indarini, E. (2019). Efektivitas Model Pembelajaran Problem Solving dan Group Investigation Terhadap Peningkatan Kemampuan Berpikir Kritis Siswa Kelas 4 SD Dalam Pelajaran 
Matematika.3(2008), 923-933.

Sugiyono. (2013). Metode Penelitian Pendidikan (Pendekatan Kuantitatif, Kualitatif, dan R\&D). Bandung: Alfabeta.17 -132.

Wardani, N. S. (2013). Implementasi Strategi Pembelajaran Sains Teknologi Masyarakat (STM) Tematik Dan Evaluasinya Dalam Kurikulum 2013 Siswa Kelas Rendah. Paper Seminar Nasional “Menyongsong Implemen tasi Kurikulum 2013" Dalam Rangka Dies Natalis ke -49 UNY.

Wardani, N. S. (2016). Pengaruh Problem Based Learning (PBL) terhadap Karakter Mahasiswa PGSD. Prosiding Seminar Nasional Menjadi Guru Inspirator UMP, 489-501. ISBN/978-602-14377-4-2. 